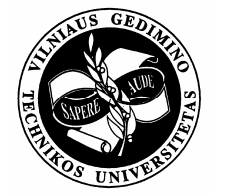

\title{
EVALUATING THE SUSTAINABILITY OF VILNIUS CITY RESIDENTIAL AREAS
}

\author{
Milda Viteikiené $\dot{~}^{1}$,Edmundas Kazimieras Zavadskas ${ }^{2}$ \\ Dept of Construction Technology and Management, Vilnius Gediminas Technical University, \\ Sauletekio al. 11, LT-10223 Vilnius, Lithuania \\ E-mail: ${ }^{1}$ mildav@adm.vtu.lt; ${ }^{2}$ edmundas.zavadskas@adm.vtu.lt \\ Received 23 Nov 2006; accepted 5 Feb 2007
}

\begin{abstract}
The objective of this article is to propose a methodology that would enable to rank residential areas according to the indices of sustainable development and to establish the rank of their priorities. The task was framed basing on the survey performed by RAIT (Market analysis and group of survey) for evaluation of the most desirable residential area in Vilnius city. Vilnius residents took part in this survey. Only Vilnius city residential areas and their characteristic indices were sorted out from the survey performed by RAIT. A system of 22 indices defining the sustainability aspects was compiled. Residential areas were evaluated for their facilities, residential and business environment. On the basis of the surveys performed by experts, the significances of indices were determined. Application of multipurpose evaluation method COPRAS (Complex Proportional Assessment) led to establishment of the rank of priorities of residential areas in respect of their sustainability.
\end{abstract}

Keywords: sustainable development, residential areas of the city, COPRAS, evaluation.

\section{Introduction}

Sustainable development is one of the major problems all over the world. Probably the utmost problem of sustainability is alterations of social needs. People, business, society and authority can act together in seeking for development of economy, environmental and social welfare.

According to the classical conception, sustainable development consists of social, economical and environmental components. Evaluation of a sustainable city residential area in these aspects shows which residential area is desirable for residents.

Sustainable development is becoming a dominating principle in planning a new and compact format of a city residential area. Conception of impossibility to live in such residential areas as we have now urges us to reconsider our present practice of city planning. Acceptance of new and innovative ideas in the process of city planning is a new challenge for development of sustainable landscape.

Many countries in the world face problems of sustainable development in the city and residential areas.

The contributors make suggestions how to solve water supply problems in cities. Zhang et al [1] analysed sustainable urban development indicators. Diepen and Voogd [2] studied peculiarities of urban transport planning in a sustainable city. The research object chosen by Kountouris et al [3] is sustainable development of urban environment. Henn and Henning [4] analysed the indicators of economic, social and environmental sustainability. Brenheny and Archer [5] concern with urban density researches, influences of local authority on sustainable development, also with communication problems between residential districts. Banister [6] characterised obstacles that hinder creating sustainability in a city.

Rudlin and Falk [7] described the lifestyle of a sustainable city. To avoid the mistakes made in the Soviet period, the living environment, according to a town - planning specialist Burinskiene [8], should be created in such a way that a dwelling, a garage for a motor car and a recreational space are concentrated, rather than being located in different parts of the city. A residential area should be not too large allowing for the residents to maintain friendly relations with each other and order in a clearly outlined area. A structural core of the residential area should be a group of houses sharing a courtyard and other objects on its territory. A number or group of residential houses with child care institutions, recreational spaces and playgrounds for all groups of inhabitants, as well as green zones, approach roads, parking spaces etc make an urban residential area.

Turskis et al [9] developed a methodology that can help city planners to determine and localise problems of urban fabric density, to enhance motivation and versatility of decisions. Melchert [10] analysed building ecology and urban sustainability planning problems in developing countries. Zavadskas et al [11] develop a model of sustainable urban formation by undertaking a complex analysis of micro, meso and macro environmental factors affecting it and to present recommendations for the increase of its competitive abilities.

West Australian Planning Commission has created the strategie control of the attractive residential area development [12].

Engel-Yan et al [13] emphasise the role of interface in promoting sustainability at the residential area scale. 
Priemus [14] introduces us to development of sustainability and stability of the cities in Holand.

In this paper a multipurpose evaluation method COPRAS is used to determine the most sustainable residential area.

Sustainable residential areas can be characterised by social, economical, environmental and cultural indicators.

\section{Indices defining a sustainable residential area}

A district should meet the requirements of a sustainable development, embracing ecological, social, construction and traffic aspects. Its facilities are coordinated and handy to all residents [15].

Residential areas are defined by economic, ecologic, social, technical, engineering indices. These issues were discussed in a number of publications.

The initiative committee of a sustainable district points out the following indices [15]:

- water;

- land use/agriculture;

- transport;

- buildings/facilities;

- business/industry;

- composting/processing;

- community/education;

- parks/green areas.

The European Academy of the urban environment provides a model of sustainable district development [16]:

- balance between work and leisure time;

- nature preservation;

- priorities for pedestrians, cyclists and public transport;

- economic operation of energy generation and heating systems;

- construction of energy saving houses;

- opening of district supermarkets to satisfy everyday needs;

- opening of elementary schools and day centres;

- opening of public rest places in nature;

- diversity of forms of constructed buildings;

- arable land and agriculture;

- balance between social groups.

In Lithuania the sustainable district projects have not been developed as much as abroad. Development of such projects requires a lot of efforts and means as well as financing by state institutions; nevertheless, establishment of such district is beneficial to all residents in ecological and social aspects. Life in harmony with nature, environment and surrounding people is essential for each individual.

Woodcock emphasises the major aspects of a sustainable urban residential area [17]:

1) excellent city development and architecture;

2) privileges for the residents;

3) considers local needs and characteristics;

4) possibilities to acclimatise and change;

5) takes care of public space and new houses projects;
6) pursues ways to maintain and renovate buildings of historic value;

7) takes care of the design of such buildings for the benefit of society and by seeking promotion from a private sector;

8) enhances the quality of private territories.

Thus it is essential to develop the spirit of location by enhancing the life quality. This may be achieved by development of an effective public transport network, safe streets, city design, retailing sector, landscaping (open space) network, local employment basis.

Grant et al [18] emphasised the importance of protecting landscape and ecosystems. They urge the architects and designers to revise the priorities in planning the residential areas, taking into account the significant processes and functions associated with landscape preservation. Planning of sustainable districts embraces not only new concepts and ideas, but also new ways of land development. The authors of the present paper believe that communities of sustainable districts should be guided by the following principles/goals:

- to maintain and restore natural processes and functions of the environment;

- to minimise the effect of residential areas on ecosystems;

- to save natural resources for the future generations;

- to reduce waste production by the residential areas;

- to increase the community involvement in developing a sustainable residential areas;

- to support a healthy social environment.

The concept of Kronsberg city development and landscape sustainable development [19] emphasises the following aspects:

- description of large scale social and ecological development concepts;

- overall development of the project and integrated planning process;

- innovatory structure of communications maintaining the process of development;

- education and curricula associated with sustainable development;

- participation planning processes by involving residents and other people.

There is no uniform system of a sustainable city residential area, therefore development of a system of indices of a sustainable city residential area shall consider the needs of the residents as well as social, environmental, technical aspects.

\section{Selection of the surveyed object}

In order to analyse the sustainability of city residential areas Vilnius city was selected as Vilnius is the principal administrative centre of Lithuania with the highest concentrated economic potential, the highest number of inhabitants and the leading political, economical, social and cultural centres.

Evaluation of the sustainability of Vilnius city residential areas was based on RAIT survey of Vilnius city [20]. 
41 districts and parts of districts were intercompared: Centras I, Centras II, Žvèrynas, Senamiestis, Naujamiestis, Vilkpėdè, Šnipiškès, Žirmūnai, Žirmūnai II, Dvarčionys, Antakalnis, Belmontas, Rasos, Pavilnys, Naujininkai, Lazdynai, Karoliniškès, Viršuliškès, Šeškinè, Baltupiai, Santariškès, Verkiai, Naujoji Vilnia, Žemieji Paneriai, Vaidotai, Kirtimai, Užsienis, Aukštieji Paneriai, Gariūnai, Grigiškès, Justiniškès, Pašilaičiai, Pilaitė II, Valakampiai, Pilaitè I, Medžiakalnis, Fabijoniškès, Gureliai, Trakų Vokè, Kuprijoniškès, Tarandè.

The survey was carried out by direct interviewing using set questionnaire forms where the interviewers recorded the respondents' answers.

In total 2575 permanent residents of Vilnius city, 16 to 74 years of age took part in the survey [20].

To determine the most sustainable Vilnius city residential area, 29 residential areas of Vilnius city were selected from RAIT survey (Fig): Centras I, Centras II, Žvėrynas, Senamiestis, Naujamiestis, Šnipiškès, Žirmūnai, Žirmūnai II (Šiaurès miestelis), Antakalnis, Rasos, Naujininkai, Lazdynai, Karoliniškès, Viršuliškès, Šeškinè, Baltupiai, Santariškès, Verkiai, Naujoji Vilnia, Žemieji Paneriai, Aukštieji Paneriai, Justiniškès, Pašilaičiai, Pilaitè II (Northern part), Valakampiai, Pilaitè I, Fabijoniškès, Vilkpėdè, Grigiškès.

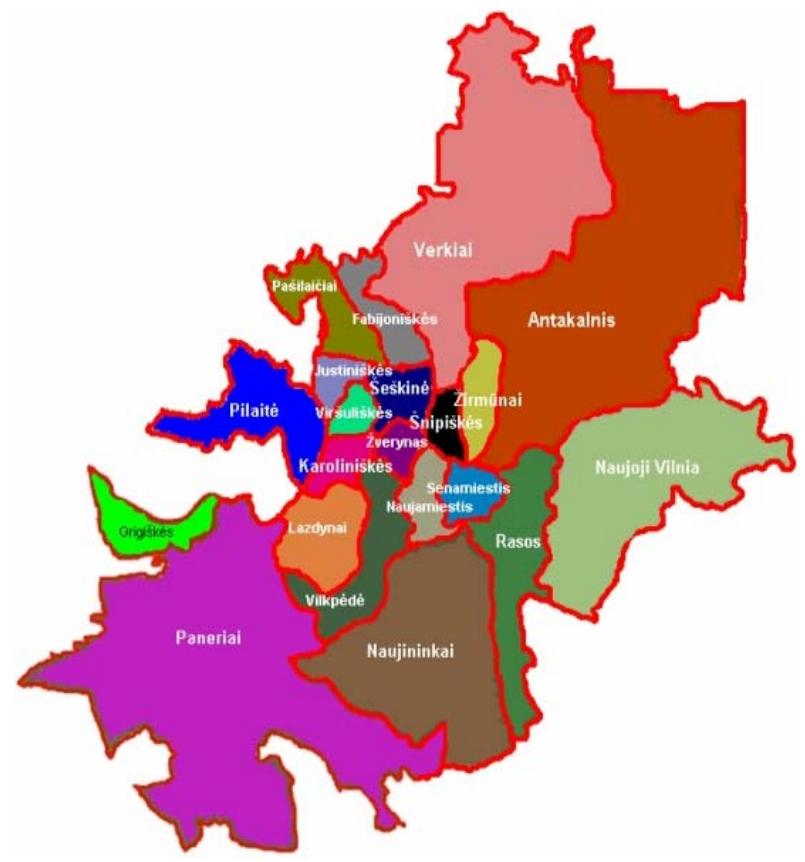

District communities of Vilnius city municipality

RAIT survey evaluates Vilnius city residential area by 22 indices that correspond to sustainability aspects (Table 1): City centre is close (points); Safe (points); Extensive supply of trade services (points); School is close (points); Kindergarten is close (points); Extensive supply of recreation (points); Clean air (points); Nice environment (points); Good transport service with the centre (points); Good transport service with the work place (points); Well attended environment (points); No noise (points); No drugaddicts (points); Policlinics is close (points); Drugstore is close (points); Good facilities for sports (points); Many cultural institutions (points); No alcohol addicts are in sight (points); No derelicts are in sight (points); Work place is close (points); Nice architecture of buildings (points); Well attended parks (points).

All these indices were taken from RAIT survey [20] where the residents evaluated the desirability of a residential area in points ( 5 points - excellent, 4 points - very good, 3 points - good, 2 points - bad, 1 point - very bad).

\section{Determination of opinion compatibility among the residents}

To determine the significances of the criteria, the expert judgement method proposed by Kendall [21] was used. Zavadskas et al [22] discussed the application of this method in the construction field.

Having determined the numerical values of indices, the significance (importance) of the indices is determined. The significances of the indices on sustainability of city residential areas are evaluated in numerical scale from 1 to 22 : 1 - insignificant index, $22-$ very significant index.

45 residents of Vilnius city residing in these residential areas were interviewed for determining significances of the project indices. These residents have sufficient information about their residential area and are most concerned persons in establishing the value of sustainability of the city residential area.

This expert judgement method was implemented at the following stages [22]:

- Interview;

- Calculation of values $t$

- Calculation of weights $q$;

- Calculation of values $S$;

- Calculation of values $T_{k}$;

- Calculation of values $W$;

- Calculation of values $\chi^{2}$;

- Testing the statement $\chi^{2}>\chi_{t b l}^{2}$.

The values $t_{j k}$ for statistical processing were obtained by interviewing the respondents. The average criterion value $\overline{t_{j}}$ was calculated by the formula:

$$
\overline{t_{j}}=\frac{\sum_{k=1}^{r} t_{j k}}{r},
$$

where $t_{j k}$ is the ranking of the $j$ criterion by the $k$ respondent and $r$ is number of respondents.

The weights of the criteria were calculated by dividing the sum of the criteria average values by the average value of each criterion:

$$
q_{j}=\frac{\bar{t}_{j}}{\sum_{j=1}^{n} \overline{t_{j}}} .
$$

The total weight of the criteria must be equal to one:

$$
\sum_{j=1}^{n} q_{j}=1,0
$$


Reliability of the data can be expressed by the coefficient of concordance (agreement) of the respondents' opinions by describing the extent to proximity of individual views. In cases with reiterated ranks for same parameters, as in our case, the coefficient of concordance is:

$$
W=\frac{12 S}{r^{2}\left(n^{3}-n\right)},
$$

where $S-$ the total square deviation of the rankings of each criterion, $T_{k}$ the index of reiterated ranks in the $r$ rank, $r$ the number of respondents and $n$ the number of evaluation criteria.

The deviation of the criterion ranking:

$$
S=\sum_{j=1}^{n}\left[\sum_{k=1}^{r} t_{j k}-\frac{1}{n} \sum_{j=1}^{n} \sum_{k=1}^{r} t_{j k}\right]^{2},
$$

where $t_{j k}$ is the rank conferred by the $k$ respondent to the $j$ criterion.

The significance $\chi^{2}$ of the concordance coefficient is calculated as follows:

$$
\chi^{2}=\frac{12 S}{r n(n+1)} .
$$

Kendall [21] has shown that, when $n>7$, the value $\chi^{2}=W \times r \times(n-1)$ has a distribution with degrees of freedom $v=n-1$, where $n$ is the number of criteria considered and $r$ the number of experts. It has been proved that if the calculated value $\chi^{2}$ is larger than the critical tabular value $\chi^{2} t b l$ for the pre-selected level of significance (eg $\alpha=0,05$ ), then the hypothesis about the agreement of independent experts judgements is not rejected. If the $\left.\chi_{a, v}{ }^{2}\right\rangle \chi_{t b l}^{2}$ the significance of concordance coefficient exists on $\alpha$ level, then the agreement of experts' opinions is satisfactory and group opinion is established. Otherwise, when $\left.\chi_{a, v}{ }^{2}\right\rangle \chi_{t b l}^{2}$ is obtained, the respondents' opinions are not in agreement, which implies that they differ substantially and the hypothesis on the rank's correlation cannot be accepted.

The concordance coefficient based on the criteria weights is $\chi^{2}=445,86$ greater than $\chi^{2} t b l$, the hypothesis on the rank's correlation cannot be accepted. The degrees of freedom $(v=n-1=22-1=21)$, and pre-selected level of significance is $\alpha=0,01$ (or error probability $\mathrm{P}=1 \%)$; in that case we have the value of $\chi^{2} t b l$ equal to 38,93 [23]. Since $445,86>38,93 \alpha=0,01$, and $v=21$, then the assumption is made that the coefficient of concordance is significant and expert rankings are in concordance with $99 \%$ probability.

\section{Evaluation of city residential areas by using COPRAS method}

This method assumes direct and proportional dependence of significance and priority of investigated versions on a system of criteria adequately describing the alternatives and on values and significances of the criteria.

Application of multipurpose evaluation method COPRAS led to establishment of the rank of priorities of residential areas in respect of their sustainability.

Description of COPRAS methods and possibilities of its application are published in a number of papers [24-29].

The determination of significance and priority of alternatives is carried out in 4 stages [30]:

Stage 1: The weighted normalised decision making matrix $D$ is formed. The purpose of this stage is to receive dimensionless weighted values from the comparative indexes. When the dimensionless values of the indexes are known, all criteria, originally having different dimensions, can be compared. The following formula is used for this purpose:

$$
d_{i j}=\frac{x_{i j} \cdot q_{j}}{\sum_{j=1}^{n} x_{i j}} \quad i=\overline{1, m} ; \quad j=\overline{1, n}
$$

where $x_{i j}$ - the value of the $i$-th criterion in the $j$-th alternative of a solution; $m$ - the number of criteria; $n-$ the number of the alternatives compared; $q i$ - significance of $i$-th criterion.

The sum of dimensionless weighted index values $d_{i j}$ of each criterion $x_{i}$ is always equal to the significance $q_{i}$ of this criterion:

$$
q_{i}=\sum_{j=1}^{n} d_{i} \quad j \quad i=\overline{1, m} ; \quad j=\overline{1, n} .
$$

In other words, the value of significance $q_{i}$ of the investigated criterion is proportionally distributed among all alternative versions $a_{j}$ according to their values $x_{i j}$.

Stage 2: The sums of weighted normalised indexes describing the $j$-th version are calculated. The versions are described by minimising indexes $S_{-j}$ and maximising indexes $S_{+j}$. The lower value of minimising indexes is better and the greater value of maximising indexes is better. The sums are calculated according to the formula:

$$
S_{+j}=\sum_{i=1}^{m} d_{+i j} ; \quad S_{-j}=\sum_{i=1}^{m} d_{-i j} \quad i=\overline{1, m} ; \quad j=\overline{1, n} .
$$

In this case, the values $S_{+j}$ [the greater is this value (project 'pluses'), the more satisfied are the interested parties] and $S_{-j}$ [the lower is this value (project 'minuses'), the better is goal attainment by the interested parties] express the degree of goals attained by the interested parties in each alternative residential area. In any case the sums of 'pluses' $S_{+j}$ and 'minuses' $S_{-j}$ of all alternative projects are always respectively equal to all sums of significances of maximising and minimising criteria:

$$
\begin{aligned}
& S_{+}=\sum_{j=1}^{n} S_{+j}=\sum_{i=1}^{m} \sum_{j=1}^{n} d_{+i j}, \\
& S_{-}=\sum_{j=1}^{n} s_{-j}=\sum_{i=1}^{m} \sum_{j=1}^{n} d_{-i j}, \quad i=\overline{1, m} ; \quad j=\overline{1, n} .
\end{aligned}
$$

In this way, the calculations made may be additionally checked. 


\begin{tabular}{|c|c|c|c|c|c|c|c|c|c|c|c|c|c|c|c|c|c|c|c|}
\hline No & Evaluation criteria & 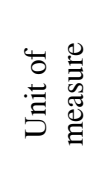 & * & $\begin{array}{l}\text { Signifi- } \\
\text { cance }\end{array}$ & 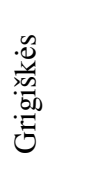 & 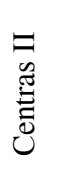 & 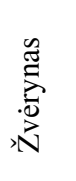 & 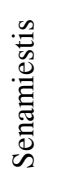 & 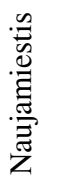 & 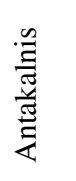 & $\begin{array}{l}\tilde{O} \\
\stackrel{0}{\tilde{a}} \\
\tilde{\sim}\end{array}$ & 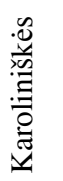 & 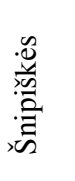 & 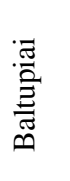 & 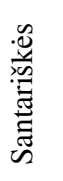 & 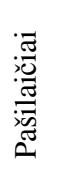 & 寻 & 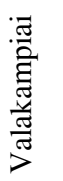 & \\
\hline 1 & City centre is close & Points & + & 0,042 & 3,8 & 5 & 5 & 4,9 & 4,9 & 4,7 & 4,5 & 4,2 & 4,8 & 4,3 & 3,4 & 3,3 & 3,5 & 3,4 & 3,1 \\
\hline 2 & $\begin{array}{l}\text { Extensive supply of trade } \\
\text { services }\end{array}$ & Points & + & 0,03 & 3,4 & 4,4 & 3,3 & 3.6 & 4.2 & 3.6 & 2.3 & 4.4 & 4.6 & 4 & 3.7 & 4,2 & 2.5 & 2.2 & 3.1 \\
\hline 3 & School is close & Points & + & 0,059 & 4,4 & 4,8 & 4,8 & 4,6 & 4,5 & 4,6 & 3,6 & 4,8 & 4,8 & 4,5 & 3,8 & 4,6 & 3,1 & 2,7 & 4 \\
\hline 4 & Kindergarten is close & Points & + & 0,034 & 4,5 & 4,9 & 4,9 & 4,4 & 4,4 & 4,1 & 3,6 & 4,9 & 4,8 & 4,4 & 1,9 & 4,6 & 2,8 & 3,1 & 3,7 \\
\hline 5 & $\begin{array}{l}\text { Extensive supply of } \\
\text { recreation }\end{array}$ & Points & - & 0,027 & 2,4 & 4,2 & 2,7 & 4,1 & 3,4 & 2,4 & 1,7 & 3,2 & 4,4 & 2,6 & 2,3 & 2,8 & 1,7 & 1,9 & 2,6 \\
\hline 6 & Clean air & Points & + & 0,071 & 4 & 3 & 3,4 & 3,2 & 2,8 & 3,8 & 3,5 & 3,8 & 3 & 4,1 & 4 & 3,7 & 4,8 & 4,6 & 4,6 \\
\hline 7 & Nice environment & Points & + & 0,061 & 4,4 & 4 & 4,6 & 4,3 & 3,4 & 4,1 & 3,9 & 4,2 & 3,2 & 4,5 & 4,2 & 3,8 & 4 & 4,7 & 4,1 \\
\hline 8 & Safe & Points & + & 0,069 & 3 & 3,2 & 3,9 & 3,4 & 2,9 & 3,4 & 3,4 & 2,7 & 2,9 & 3,6 & 3,4 & 3,3 & 3,4 & 3,8 & 3,8 \\
\hline 9 & $\begin{array}{l}\text { Good transport service } \\
\text { with the centre }\end{array}$ & Points & + & 0,064 & 4,1 & 5 & 5 & 4,7 & 4,8 & 4,7 & 4,1 & 4,5 & 4,8 & 4,4 & 4,2 & 4,1 & 3,9 & 3,4 & 3,3 \\
\hline 10 & $\begin{array}{l}\text { Good transport service } \\
\text { with the work place }\end{array}$ & Points & + & 0,06 & 3,6 & 4,3 & 4,2 & 4,3 & 4,3 & 3,8 & 3,8 & 3,8 & 4,3 & 4,1 & 3,8 & 4 & 4,2 & 3 & 3,7 \\
\hline 11 & $\begin{array}{l}\text { Well attended environ- } \\
\text { ment }\end{array}$ & Points & + & 0,047 & 3,4 & 3,6 & 3,9 & 3,4 & 3,4 & 3,5 & 2,8 & 3,7 & 3,1 & 3,8 & 4 & 3,9 & 3,9 & 3,6 & 3,7 \\
\hline 12 & No noise & Points & + & 0,068 & 3,8 & 3,3 & 4,1 & 3,7 & 3,1 & 3,3 & 3,8 & 3,4 & 3 & 4 & 4,7 & 3,9 & 4,8 & 4,4 & 4,5 \\
\hline 13 & No drug-addicts & Points & + & 0,048 & 2,8 & 3,4 & 2,8 & 3,1 & 2,9 & 2,8 & 4,1 & 2,1 & 2,6 & 3,4 & 4 & 3,4 & 3,7 & 3,8 & 4 \\
\hline 14 & Policlinics is close & Points & + & 0,035 & 4,4 & 4,3 & 3,5 & 3,9 & 4,3 & 4,6 & 3,8 & 4,9 & 3,7 & 3,7 & 3,9 & 4 & 3,3 & 3,5 & 4,1 \\
\hline 15 & Drugstore is close & Points & + & 0,045 & 4,4 & 4,8 & 4,8 & 4,4 & 4,7 & 4,7 & 3,9 & 4,9 & 4,6 & 4,9 & 4,7 & 4,8 & 4,1 & 3,4 & 4,5 \\
\hline 16 & Good facilities for sports & Points & + & 0,023 & 2,9 & 3,8 & 4,6 & 3,6 & 3,9 & 3,8 & 2,9 & 4,6 & 3,6 & 3,8 & 4,1 & 3,5 & 3,1 & 4,8 & 3,6 \\
\hline 17 & Many cultural institutions & Points & - & 0,016 & 2 & 4,1 & 2,6 & 4 & 3 & 2,3 & 1,6 & 2,2 & 3 & 2 & 2,1 & 2,2 & 1,3 & 1,3 & 2,1 \\
\hline 18 & $\begin{array}{l}\text { No alcohol addicts are in } \\
\text { sight }\end{array}$ & Points & + & 0,042 & 2,6 & 3,2 & 2,5 & 2,7 & 2,6 & 2,2 & 3,2 & 1,8 & 2 & 2,7 & 3,3 & 3 & 2,3 & 3,2 & 3,4 \\
\hline 19 & No derelicts are in sight & Points & + & 0,026 & 3 & 2,9 & 2,5 & 2,7 & 2,5 & 2,3 & 3,8 & 2,1 & 2,5 & 2,8 & 3,2 & 3,3 & 2,1 & 3,4 & 3,3 \\
\hline 20 & Work place is close & Points & + & 0,075 & 3,3 & 4,2 & 3,7 & 3,9 & 3,8 & 2,9 & 3,3 & 3 & 3,8 & 3,1 & 2,9 & 3,2 & 3,8 & 2,6 & 3,2 \\
\hline 21 & $\begin{array}{l}\text { Nice architecture of build- } \\
\text { ings }\end{array}$ & Points & + & 0,044 & 2,9 & 4,3 & 3,7 & 4,5 & 3,3 & 2,9 & 2,7 & 2,4 & 3,3 & 2,8 & 3,2 & 2,9 & 2,5 & 3,4 & 2,8 \\
\hline 22 & Well attended parks & Points & + & 0,014 & 3 & 3,4 & 4 & 3,2 & 3,3 & 3,4 & 2,6 & 3,3 & 3,3 & 3,2 & 3,3 & 2,6 & 3 & 3,5 & 3,5 \\
\hline
\end{tabular}

\footnotetext{
* A sign +(-) indicates that a higher (lower) value of the criteria is better for residents.
} 
Stage 3: The significance (efficiency) of comparative versions is determined on the basis of describing positive ('pluses') and negative ('minuses') characteristics. Relative significance $Q_{j}$ of each project $\mathrm{a}_{\mathrm{j}}$ is found according to the formula:

$$
Q_{j}=S_{+j}+\frac{S_{-\min } \cdot \sum_{j=1}^{n} S_{-j}}{S_{-j} \cdot \sum_{j=1}^{n} \frac{S_{-\min }}{S_{-j}}}, \quad j=\overline{1, n} .
$$

Stage 4: Priority determination of residential area. The greater is the $Q_{j}$, the higher is the efficiency (priority) of the project.

Having made the calculations, we get a sustainable residential area of Vilnius city.

\section{Conclusions}

The sustainable city development and residential areas have a large number of indices/indices systems in the world. With reference to these indices/indices systems has been made the system of 22 indicators defining the sustainability of residential areas.

Basing on multipurpose evaluation method COPRAS, the most sustainable residential area was determined and evaluated by 22 sustainability development indices. It was established that the multipurpose COPRAS method is suitable for determining the sustainable district.

An analysis was done comparing all areas named above. There we see the most problematic areas in which quality of living must be improved. Improvement of living quality is a target of government and municipality.

Ranking of priorities of city residential areas was compiled: Žvèrynas, Centras II, Baltupiai, Senamiestis, Pilaite I, Pilaitè II, Santariškès, Naujamiestis, Pašilaičiai, Antakalnis, Valakampiai, Grigiškès, Rasos, Karoliniškès, Šnipiškès, Šeškinè, Fabijoniškès, Centras I, Lazdynai, Naujoji Vilnia, Justiniškès, Žirmūnai II, Viršuliškès, Naujininkai, Verkiai, Žemieji Paneriai, Žirmūnai, Aukštieji Paneriai, Vilkpèdè.

The most sustainable residential area is Žvèrynas. This area is close to the centre of Vilnius, nice looking architecture, lovely surrounding, a lot of green zones and well - organised infrastructure sollutions.

\section{References}

1. ZHANG, K.; HE, X. and WEN, Z. Study of indicators of urban environmentally sustainable development in China. International Journal of Sustainable Development, 2003, 6(2), p. 170-182.

2. DIEPEN, A. and VOOGD, H. Sustainability and planning: does urban form matter? International Journal of Sustainable Development, 2001, 4(1), p. 59-74.

3. KOUNTOURIS, K.; GENERALIS, G. and MYLONAKIS J. Urban sustainable environmental development patterns in modern cities. International Journal of Environment and Sustainable Development, 2005, 4(4), p. $395-411$.
4. HENN, P. and HENNING, J. Urban agriculture and sustainable urban systems: a benefits assessment of the garden movement in Havana, Cuba. International Journal of Environment and Sustainable Development, 2002, 1(3), p. 202-209.

5. BREHENEY, M. and ARCHER, S. Urban densities, local polices and sustainable development. International Journal of Environment and Pollution, 1998, 10(1), p. 126150.

6. BANISTER, D. Barriers to the implementation of urban sustainability. International Journal of Environment and Pollution, 1998, 10(1), p. 65-83.

7. RUDLIN, D. and FALK, N. Sustainable Urban Neighborhood: Building the 21st Century Home, Architectural Press, 1999. 288 p.

8. BURINSKIENĖ, M. Sustainable urban development (Subalansuota miestu plètra). Monograph. Vilnius: Technika, 2003. 251 p. (in Lithuanian).

9. TURSKIS, Z.; ZAVADSKAS, E. K. and ZAGORSKAS, J. Sustainable city compactness evaluation on the basis of gis and bayes rule. International Journal of Strategic Property Management, 2006, 10(3), p. 185-207.

10. MELCHERT, L. The Dutch sustainable building policy: A model for developing countries? Building and Environment, 2007, 42(2), p. 893-901.

11. ZAVADSKAS, E. K.; KAKLAUSKAS, A.; VAINIŪNAS, P. and ŠAPARAUSKAS, J. A model of sustainable urban development formation. International Journal of Strategic Property Management, 2004, 8(4), p. 219-229.

12. Liveable neighbourhoods: guiding new developments for a more sustainable urban future.

www.sustainability.dpc.wa.gov.au/CaseStudies/LivableHo ods/LiveableNeighbourhoods.htm [revised 2701 2006].

13. ENGEL-YAN, J.; KENNEDYS, C.; SAIZ, S. and PRESSNAIL, K. Toward sustainable neighbourhoods: the need to consider infrastructure interactions. Canadian Journal of Civil Engineering, 2005, 32(1), p. 45-57.

14. PRIEMUS, H. The long road towards sustainable cities: the Dutch case. Eolss Publishers, Oxford, UK, 1999.

15. The sustainable region initiative. http://www.gvrd.bc.ca/sustainability [revised 1411 2005].

16. European academy of the urban environment. http://www.eaue.dewinuwd/198.htm [revised 1411 2005].

17. WOODCOCK, S. Sustainability design guidelines for urban release areas. Institute for Sustainable Futures, University of Technology, Sydney, 2000. 29 p.

18. GRANT, J.; MANUEL P. and JOUDREY, D. A landscape framework for planning residential environments. Journal of the American Planning Association, 1996, 62(3), p. 331-44.

19. Hannover: Kronsberg, a new sustainable development as part of EXPO 2000. http://www.eaue.de/winuwd/ 190.htm. [revised 2701 2006].

20. RAIT the residents of Vilnius city (RAIT Vilniaus miesto gyventojai), 2005. 125 p. (in Lithuanian).

21. KENDALL, M. G. Rank correlation methods. 4th ed Griffin, London, 1970.

22. ZAVADSKAS, E. K. Complex estimation and choice of resource saving decisions in construction (Комплексная оценка и выбор ресурсосберегающих решений в строительстве). Vilnius: Mokslas, 1987. 210 p. (in Russian). 
23. KRUOPIS, J. Statistics (Matematinè statistika). Vilnius: Mokslo ir enciklopedijų leidykla, 1993. 412 p. (in Lithuanian).

24. ZAVADSKAS, E. K. and VILUTIENĖ, T. Multi-criteria analysis of multi-family apartment blocks maintenance service packages. Journal of Civil Engineering and Management, 2004, 10, Suppl 2, p. 143-152 (in Lithuanian).

25. VILUTIENĖ, T. and ZAVADSKAS, E. K. The application of multicriteria analysis to decision support for the facility management of a city's residential district. Journal of Civil Engineering and Management, 2003, 10(4), p. 241-252.

26. ZAVADSKAS, E. K.; KAKLAUSKAS, A. and KVEDERYTĖ, N. Multivariant design and multiple criteria analysis of building life cycle. Informatica, 2001, 12(1), p. 169-188.
27. ZAVADSKAS, E. K.; KAKLAUSKAS, A.; BANAITIS, A. and KVEDERYTE், N. Housing credit access model: The case for Lithuania. European Journal of Operational Research, 2004, 155(2), p. 335-352.

28. KAKLAUSKAS, A.; ZAVADSKAS, E. K. and RASLANAS, S. Multivariant design and multiple criteria analysis of building refurbishments. Energy and Buildings, 2005, 37(4), p. 361-372.

29. ANDRUŠKEVIČIUS, A. Evaluation of contractors by using COPRAS. Technological and Economic Development of Economy, 2005, 11(3), p. 158-169 (in Lithuanian).

30. ZAVADSKAS, E. K.; SIMANAUSKAS L. and KAKLAUSKAS A. Decision support systems in construction (Sprendimu paramos sistemos statyboje). Vilnius: Technika, 1999. 235 p. (in Lithuanian).

\section{VILNIAUS MIESTO GYVENAMŲJŲ RAJONŲ DARNOS VERTINIMAS}

\section{Viteikienė, E. K. Zavadskas}

\section{Santrauka}

Straipsnio tikslas - pasiūlyti metodiką, kaip surikiuoti gyvenamuosius rajonus pagal darnios plètros rodiklius ir sudaryti jų prioritetų eilutę.

Suformuluotas uždavinys remiantis Vilniaus miesto RAIT atlikta apklausa patraukliausiam rajonui ịvertinti. Šioje apklausoje dalyvavo Vilniaus miesto gyventojai. Iš apklausos buvo atrinkti tik Vilniaus miesto gyvenamieji rajonai (mikrorajonai) ir juos apibūdinantys rodikliai. Buvo sudaryta 22 rodiklių sistema, charakterizuojanti darnos aspektus. Gyvenamieji rajonai vertinami pagal infrastruktūra, gyvenamają bei verslo aplinką. Remiantis ekspertų apklausomis, nustatyta rodiklių reikšmè. Taikant daugiatikslio vertinimo metodą COPRAS (Complex Proportional Assessment), sudaryta gyvenamujų rajonų pagal jų darną prioritetų eilutè.

Reikšminiai žodžiai: darnus vystymasis, miesto gyvenamieji rajonai, COPRAS, vertinimas.

Milda VITEIKIENE. PhD student and Assistant Professor at the Dept of Construction Technology and Management, Vilnius Gediminas Technical University. MSc degree in construction management and business (2003). Research interests: innovation, economics, marketing, management, the theory of multiple criteria decision-making in practice.

Edmundas Kazimieras ZAVADSKAS. Doctor Habil, Professor, Dr honoris causa of Poznan University of Technology, Vice Rector of Vilnius Gediminas Technical University (Lithuania). Member of Lithuanian Academy of Sciences, President of Lithuanian Operational Research Societies, President of Alliance of Experts of projects and buildings of Lithuania. Editor-in-Chief of the "Journal of Civil Engineering and Management", "Technological and Economic Development of Economy"; Editor of the "International Journal of Strategic Property Management". The author of more than 300 scientific papers, 11 books. Research interests: building technology and management, decision-making theory, automation in design, expert systems. 